\title{
Further studies on the effects of acamprosate on tolerance to the analgesic effects of morphine and NO synthesis in the brain
}

\author{
Jacqueline Sepúlveda ${ }^{1^{*}}$, Andrea Ortega ${ }^{1}$, Jorge Roa $^{2}$, Enrique Contreras ${ }^{3}$ \\ ${ }^{1}$ Department of Pharmacology, School of Biological Sciences, University of Concepción, Concepción, Chile; \\ ${ }^{*}$ Corresponding Author: jsepulve@udec.cl \\ ${ }^{2}$ Department of Physiology, School of Biological Sciences, University of Concepción, Concepción, Chile \\ ${ }^{3}$ Department of Pre-Clinical and Clinical Sciences, School of Medicine, Catholic University of the Holy Conception, Concepción, \\ Chile
}

Received 18 July 2013; revised 19 August 2013; accepted 9 September 2013

Copyright (C) 2013 Jacqueline Sepúlveda et al. This is an open access article distributed under the Creative Commons Attribution License, which permits unrestricted use, distribution, and reproduction in any medium, provided the original work is properly cited.

\begin{abstract}
The aim of this work was to investigate whether acamprosate modifies the expression of the enzyme responsible for neuronal NO synthesis (nNOS) in the nucleus accumbens (NAc) of mice chronically treated with morphine and during the abstinence syndrome induced by naloxone. The enzyme was monitored by the NADPH diaphorase method. The number of cells stained for NADPH diaphorase in the NAc of mice was counted in $\mathbf{4 0 \mu \mathrm { m }}$ thick coronal brain slices at 40X. The intensity of the histochemical reaction of stained cells from naive morphine plus saline and morphine plus acamprosate treated mice was analyzed by Image Pro Plus 4.5.1. Morphine administered in a slow release preparation increased the stain intensity of the positive neurons. The increase in the NADPH staining persisted after naloxone was given to mice chronically treated with morphine. Acamprosate antagonized the effects induced by chronic morphine treatment in the NAC of mice. These results indicate that up-regulation of nNOS in the NAc is a consequence of the sustained effects of morphine stimulation, which, in turn, may result from an increased in glutamate release during the abstinence syndrome.
\end{abstract}

Keywords: Morphine; Nitric Oxide; Nucleus Accumbens; Acamprosate

\section{INTRODUCTION}

Acamprosate is a taurine analog (calcium acetylho- motaurinate) that has received considerable attention for its ability to prevent relapse in abstinent alcoholics [1-5]. The mechanisms by which acamprosate decreases relapse to alcohol users are still poorly understood. It has been demonstrated that the drug reduces $\mathrm{Ca}^{2+}$ fluxes through voltage-operated channels and that it interacts with NMDA receptor-mediated glutamatergic neurontransmission in various brain regions with functional antagonistic properties [6-8]. The drug also inhibits the postsynaptic potential induced by glutamate in the neocortex and the hippocampus [9]. Further studies suggest that acamprosate may modify polyamine modulation of the NMDA receptor, but does not alter receptor function of the aminoacid [10].

The NAc is thought to be a determinant structure of the brain for the expression of rewarding effects of opiates [11,12]; additionally, neurochemical studies have demonstrated that the acute administration of morphine affects the concentrations of dopamine [13] acetylcholine [14], and that chronic morphine administration in rats augments glutamate release in the NAc, and in morphine-tolerant rats following naloxone administration [15].

There are now consisting evidences indicating that NO modulates several actions of opioids [16]. In mice and rats treated with morphine, the selective inhibitor of neuronal nitric oxide synthase (nNOS) 7-nitroindazole (7NI) has proven to suppress several actions induced by morphine, e.g. the activation of the extracellular signal-regulated kinase [17] and c-Fos expression in the striatum [18].

On the other hand, glutamate effects are associated with an increase in nitric oxide (NO) release [19,20]. Accordingly, an increase of glutamate effects must be ex- 
pected to induce a greater expression of nitric oxide synthase (NOS), the enzyme responsible for NO release in the central nervous system [21].

NADPH diaphorase is responsible for the calcium/ calmodulin-dependent synthesis of the guanylylcyclase activator nitric oxide from L-arginine. The enzyme selectively labels a number of discrete populations of neurons throughout the nervous system. The NADPH diaphorase histochemical technique is used for labeling nNO synthesis expression, considered to be a selective marker for distinct neural populations widely distributed throughout the CNS [22].

We have previously demonstrated that acamprosate reduces tolerance to the antinociceptive effect of morphine and the intensity of the abstinence behavior in rats chronically treated with the opiate [23]. Besides, it reduces the high levels of the excitatory amino acid observed in the nucleus accumbens (NAc) of morphine dependent rats during the withdrawal period [24]. The present work extends these studies and investigates whether acamprosate modifies the expression of NADPH diaphorase in the NAc of mice chronically treated with morphine and during the abstinence syndrome induced by naloxone, the opiate antagonist.

\section{MATERIALS AND METHODS}

\subsection{Animals and Drugs}

Male adult albino Swiss Webster mice 12 - 15 weeks of age, weighing 25 - $32 \mathrm{~g}$ from the animal reproduction laboratory of the Department of Pharmacology of the University of Concepcion were used in all experiments. Mice were housed in groups of 10 and maintained on a 12/12-h light/dark cycles at a room temperature of $22^{\circ} \mathrm{C}$ $\pm 2{ }^{\circ} \mathrm{C}$ with free access to food and water. All experiments were performed in accordance with institutional guidelines for the use of experimental animals and with the National Institutes of Health Guide for the Care and Use of Laboratory Animals.

The drugs used were morphine $\mathrm{HCl}$ (May and Baker, Dagenham, England), naloxone (Sigma, St. Louis, MO), and acamprosate (Lipha, Lyon, France). All other chemical were purchased from Sigma, St. Louis, MO.

\subsection{Induction of Morphine Dependence}

For the induction of chronic morphine effects, the opiate was administered in a suspension of the following composition: morphine, as the base form, $300 \mathrm{mg}, 4.2 \mathrm{ml}$ liquid paraffin, and $0.8 \mathrm{ml}$ sorbital sesquioleate mixed with $5 \mathrm{ml}$ saline. After $30 \mathrm{~h}$ the animals were sacrificed and destined for histological analyses.

For the induction of the withdrawal syndrome, morphine $(300 \mathrm{mg} / \mathrm{kg})$ was administered $30 \mathrm{~h}$ before the i.p. administration of $4 \mathrm{mg} / \mathrm{kg}$ naloxone. To test the effect of acamprosate $(100 \mathrm{mg} / \mathrm{kg})$ on the expression of NADPHdiaphorase in morphine-dependent mice, this drug was i.p. administered during the chronic morphine treatment according to the following schedule: $30 \mathrm{~min}$ before and 12 and $24 \mathrm{~h}$ after the priming dose of morphine. Control groups were injected with the vehicle instead of acamprosate.

\subsection{Histological Preparations}

Mice destined for histological analyses were anesthetized with chloral hydrate $(10 \mathrm{ml} / \mathrm{kg}$ solution $5 \% \mathrm{w} / \mathrm{v})$ and after the induction of anesthesia; animals were injected with heparin (500 UI). Initially, isotonic saline solution $(50 \mathrm{ml})$ for the intracardiac perfusion was used to flush out the blood, after which a mixture containing $4 \%$ $(\mathrm{w} / \mathrm{v})$ depolymerized paraformaldehyde in $0.1 \mathrm{M}$ phosphate buffer (PBS), pH 7.3, was perfused for $20 \mathrm{~min}$.

The brains were dissected out, cut into blocks, and post-fixed in the same solution for $4 \mathrm{hr}$ at $4^{\circ} \mathrm{C}$. Tissue blocks were cryoprotected with $30 \%(\mathrm{w} / \mathrm{v})$ sucrose in PBS until they sank, after which they were quickly frozen and stored at $-80^{\circ} \mathrm{C}$. Tissue blocks were cut at $40 \mu \mathrm{m}$ along coronal planes with a freezing sliding microtome (Leica SM 2000R, Germany) and collected in six series in cold PBS. One of these series was stained with the NADPH-diaphorase histochemical technique.

\subsection{NADPH Histochemistry}

Free-floating sections were rinsed in PBS $(3 \times 10 \mathrm{~min})$ and incubated at $37^{\circ} \mathrm{C}$ in the darkness in a medium containing $0.08 \%(\mathrm{w} / \mathrm{v})$ Triton $\mathrm{X}-100,0.8 \mathrm{M}$ nitrobluetetrazolium, and $1 \mathrm{M} \beta$-NADPH in $0.1 \mathrm{M}$ Tris-HCl, $\mathrm{pH} 8.0$, for $90-120 \mathrm{~min}$. The reaction was controlled under the microscope to avoid undesirable formation of formozan crystals, and stopped with cold PBS. Stained sections were mounted onto gelatin-coated slides, dried overnight at $37^{\circ} \mathrm{C}$, dehydrated, cleared with xylene, and cover slipped with Entellan ${ }^{\circledR}$. Controls for specificity of the NADPH histochemistry were incubated without NADPH or without chromogen. No reaction product was observed in the tissue when incubated without NADPH or without chromogen.

\subsection{Evaluation of NADPH Histochemistry}

The boundaries of the region of the NAc were determined, and NADPH stained cells of this nucleus were counted. These planimetric analyses were performed in four consecutive sections from the same series, corresponding to Bregma levels ranging from 0.60 to $1.70 \mathrm{~mm}$ [25]. Rectangular frames were captured with a $40 \mathrm{X}$ objective and positive neurons were counted in each frame. 
NADPH-histochemistry positive cells were counted only if the soma and dendrites were clearly distinguished (Carl Zeiss Series 237806 SNT Axioplan 2 Germany).

\subsection{Quantitative Morphology}

The population of cells stained for NADPH diaphorase was counted in $40 \mu \mathrm{m}$ thick coronal brain slices at $40 \mathrm{X}$. Seven toten fields of $2.8 \mu \mathrm{m}^{2}$ area, from four consecutive tissue sample sections, taken from 5 control animals and from mice from each of the experimental groups, were counted. Only cells with clear nuclear profiles, dendrites and clear borders were considered.

To ensure reliable comparisons among the different groups, one series from one animal from each group (i.e., series of sections from naive, morphine-, acamprosate- or saline-treated mice) was included in a parallel staining protocol using the same incubation medium. The intensity of the histochemical reaction of stained cells was analyzed by Image Pro Plus 4.5.1.

\subsection{Statistical Analysis}

The significance of the differences in the mean results to the different treatments were determined by analysis of variance (ANOVA) and confirmed with the StudentNewman-Keuls test. A level of probability of 0.05 was accepted as statistically significant.

\section{RESULTS}

\subsection{NADPH Positive Neurons in the NAC}

No significantly changes were found in the number of NADPH positive neurons in the NAc of mice treated with morphine, acamprosate, either alone or in combination with the opiate, when compared to the results observed in naive mice or in control animals injected with saline or vehicle. Similarly, no differences in the number of NADPH positive neurons were observed in morphine dependent mice at the end of the chronic morphine treatment or after naloxone administration (Figure 1).

\subsection{Stain Intensity of NADPH Histochemistry}

In contrast to the absence of differences in the number of neurons, the stain of positive neurons was more intense in the chronically morphine treated mice. Acamprosate significantly reduced the stain of neurons in vehicle injected rats. The drug also decreased the intensity of the stain with respect to values observed in mice treated with morphine and injected with naloxone.

Naloxone administration (20 min before the mice were sacrificed) did not change the morphine effects on the intensity of the staining (Figure 2). (a)

(b)

(c)

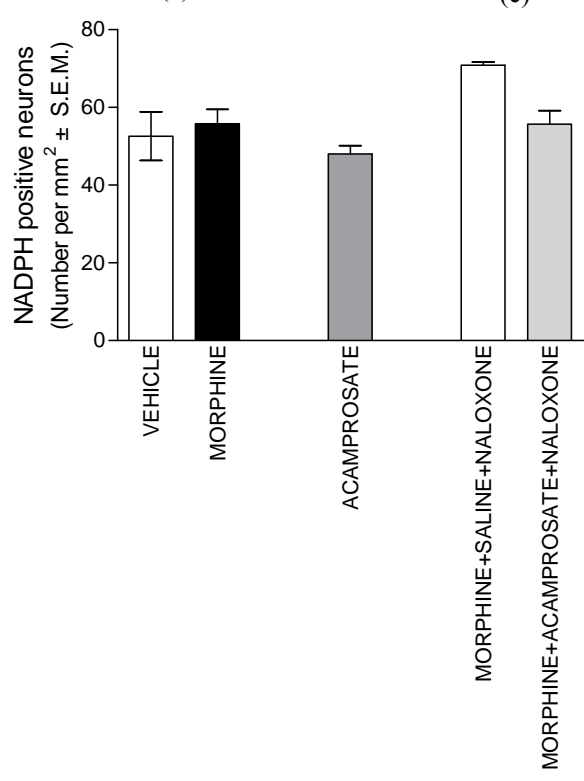

Figure 1. Number of NADPH positive neurons in the NAc. (a) Effect of morphine (300 $\mathrm{mg} / \mathrm{kg})$; (b) Effect of acamprosate (100 mg/kg); (c) Effect of acamprosate in naloxone-precipitated withdrawal of morphine treated-mice. Morphine $(300 \mathrm{mg} / \mathrm{kg})$ was administered $30 \mathrm{~h}$ before the i.p. administration of $4 \mathrm{mg} / \mathrm{kg}$ naloxone. Acamprosate $(100 \mathrm{mg} / \mathrm{kg})$ was i.p. administered $30 \mathrm{~min}$ before and 12 and $24 \mathrm{~h}$ after morphine.

\section{DISCUSSION}

Since the original work of Bredt et al. [26], it is accepted that there is a relationship between the activity of NOS and the increase of the expression of the enzyme. The neuronal isoform of the enzyme generates NO, a molecule recognized as a neurotransmitter in the central nervous system (CNS) that induces the production of cyclic GMP [27,28]. It has also been established that NADPH-diaphorase histochemical staining is a selective marker for distinct neural populations widely distributed throughout the CNS [22]. Different approaches have revealed that NADPH staining corresponds to nNOS expression [21].

In the present study, morphine induced an increase in the intensity of the NADPH staining of neurons of the NAc. The results suggest that the sustained effects of morphine are responsible for the up-regulation of NO generation.

Leza et al. have demonstrated that chronic morphine administration increases the calcium-dependent NOS activity in several areas of the brain [29]. These findings and a further study of the same laboratory [30] reporting an increase in NO synthase immunoreactivity suggest an up-regulation of the enzyme after morphine administra- 


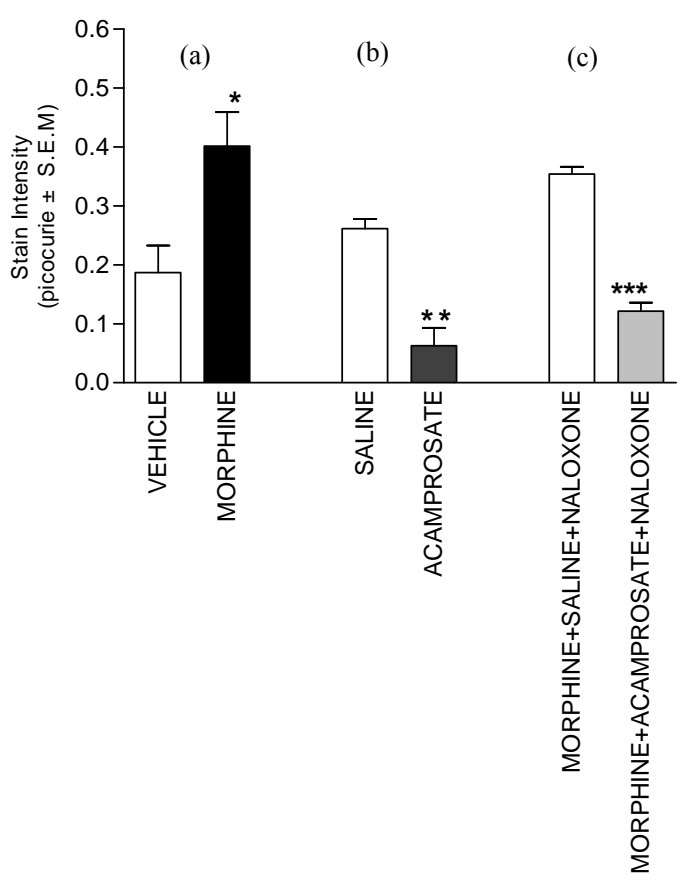

Figure 2. Stain intensity of NADPH histochemistry of the neurons of NAc in mice. (a) Effect of chronic morphine administration. Morphine $(300 \mathrm{mg} / \mathrm{kg}$ ) was administered as a slow release preparation. (b) Effect of acamprosate treatment. Acamprosate $(100 \mathrm{mg} / \mathrm{kg})$ was i.p. administered $30 \mathrm{~min}$ before and 12 and $24 \mathrm{~h}$ after the vehicle. (c) Effect of acamprosate in naloxone-precipitated withdrawal of morphine treated-mice. Morphine $(300 \mathrm{mg} / \mathrm{kg})$ was administered $30 \mathrm{~h}$ before the i.p. administration of $4 \mathrm{mg} / \mathrm{kg}$ naloxone. Acamprosate $(100$ $\mathrm{mg} / \mathrm{kg}$ ) was i.p. administered $30 \mathrm{~min}$ before and 12 and $24 \mathrm{~h}$ after morphine. ${ }^{*}$ Significantly higher than values observed in vehicle injected mice $(\mathrm{P}<0.05) .{ }^{* *}$ Significantly lower than values observed in saline injected mice $(\mathrm{P}<0.05) .{ }^{* * *}$ Significantly lower than values observed in the group injected with morphine, saline and naloxone $(\mathrm{P}<0.001)$ and significantly higher than values observed in mice treated only with acamprosate $(\mathrm{P}$ $<0.05)$.

tion. More recently, it was reported that NO synthase inhibition decreases tolerance development to morphine [31] and attenuates opioid withdrawal syndrome [32].

The exact mechanism by which morphine administration increases the expression of NADPH-diaphorase and NO synthesis is unknown, however, it has been suggested that the elevated intracellular concentration of calcium activates phospholipase $\mathrm{C}$ and protein kinase $\mathrm{C}$ [33]. The latter enzyme may enhance NMDA mediated calcium entry through glutamate, the crucial molecule involved in NO production [34].

Although the high glutamate levels during the withdrawal period are promptly decreased as a result of a counterbalance adaptation, the elevated expression of nNOS, which involves complex reactions in neuronal cells, may explain the persistence of some symptoms following the discontinuation of the drug administration. In addition, despite the increase of glutamate release observed during the abstinence period induced by naloxone [24], it is reasonable to expect that the induction of the abstinence syndrome by naloxone administration should not affect the intensity of the number of the stained neurons or the stain intensity because the animals were sacrificed $20 \mathrm{~min}$ after the induction of the syndrome, an interval not conclusive to increase gene expression and, concurrently, to enhance NO synthase activity.

Acamprosate per se, or administered in morphine treated animals, reduced the intensity of the stained neurons, suggesting a decrease in the expression of neuronal NADPH diaphorase. Effects of acamprosate per se were also observed in other areas of the brain implicated in physical dependence of morphine, including frontal cortex, midbrain and cerebellum. The drug also reduced the intensity of the staining in the group of animals treated with morphine and injected with naloxone to precipitate a withdrawal syndrome. Therefore, it seems reasonable to suppose that acamprosate does not affect glutamate release but rather that its effects are consistent with a postsynaptic interference on glutamate-NMDA receptors, perhaps modulating the spermidine site of the NMDA receptor complex as has been suggested [35,36]. Consequently, the final result of acamprosate, administered in doses that decrease the intensity of morphine dependence, is a decrease in the synthesis of NO.

The present results suggest that glutamate and NO play a role in the neurochemical adaptation, which occurs in the brain during the administration of morphine, in particular on the NAc, a structure related with chronic drug consumption. The results also support the notion that acamprosate's effects on chronic morphine responses may be partially assigned to the interaction with glutamate responses.

\section{ACKNOWLEDGEMENTS}

This work was supported by grant 203.032.011-1.0 from Vice-rectoría de Investigación y Desarrollo (VRID), Universidad de Concepción.

\section{REFERENCES}

[1] Lhuintre, J., Daoust, M., Moore, N.D., Chretien, P., Saligaut, C., Tran, G., Bosimare, F. and Hillemand, B. (1985) Ability of calcium bis acetyl homotaurine, a GABA agonist, to prevent relapse in weaned alcoholics. Lancet, 1, 1014-1016.

[2] Sass, H., Soyka, M., Mann, K. and Zieglgänsberger, W. (1996) Relapse prevention by acamprosate: Results from a placebo-controlled study on alcohol dependence. Archives of General Psychiatry, 53, 673-680. http://dx.doi.org/10.1001/archpsyc.1996.0183008002300 
6

[3] Wilde, M.I. and Wagstaff, A.J. (1997) Acamprosate: A review of its pharmacology and clinical potential in the management of alcoholic dependence after detoxification. Drugs, 53, 1038-1053. http://dx.doi.org/10.2165/00003495-199753060-00008

[4] Chick, J., Howlett, H., Morgan, M.Y. and Ritson, B. (2000) United Kingdom Multicentre Acamprosate Study (UKMAS): A 6-month prospective study of acamprosate versus placebo in preventing relapse after withdrawal from alcohol. Alcohol and Alcoholism, 35, 176-187. http://dx.doi.org/10.1093/alcalc/35.2.176

[5] Han, D.H., Lyool, I.K., Sung, Y.H., Lee, S.H. and Renshaw, P.F. (2008) The effect of acamprosate on alcohol and food craving in patients with alcohol dependence. Drug and Alcohol Dependence, 93, 279-283. http://dx.doi.org/10.1016/j.drugalcdep.2007.09.014

[6] Spanagel, R. and Zieglgänsberger, W. (1997) Anti-craving compounds for ethanol: New pharmacological tools to study addictive processes. Trends in Pharmacological Sciences, 18, 54-59.

http://dx.doi.org/10.1016/S0165-6147(97)89800-8

[7] Allgaier, C., Franke, H., Sobottka, H. and Scheibler, P. (2000) Acamprosate inhibits $\mathrm{Ca} 2+$ influx mediated by NMDA receptors and voltage-sensitive $\mathrm{Ca} 2+$ channels in cultured rat mesencephalicneurones. Naunyn-Schmiedeberg's Archives of Pharmacology, 362, 440-443. http://dx.doi.org/10.1007/s002100000285

[8] Bachteler, D., Economidou, D., Danysz, W., Ciccocioppo, R. and Spanagel, R. (2005) The effects of acamprosate and neramexane on cue-induced reinstatement of ethanol-seeking behavior in rat. Neuropsychopharmacology, 30, 1104-1110. http://dx.doi.org/10.1038/sj.npp.1300657

[9] Zeise, M.L., Kasparov, S., Capogna, M. and Zieglgänsberger, W. (1993) Acamprosate (calcium acetyl homotaurinate) decreases postsynaptic potentials in the rat neocortex: Possible involvement of excitatory amino acid receptors. European Journal of Pharmacology, 231, 47-52. http://dx.doi.org/10.1016/0014-2999(93)90682-8

[10] Popp, R.L. and Lovinger, D.M. (2000) Interaction of acamprosate with ethanol and spermine on NMDA receptors in primary cultured neurons. European Journal of Pharmacology, 394, 221-231. http://dx.doi.org/10.1016/S0014-2999(00)00195-3

[11] Koob, G.F., Wall, T.L. and Bloom, F.E. (1989) Nucleus accumbens as a substrate for the aversive stimulus effects of opiate withdrawal. Psychopharmacology, 98, 530-534. http://dx.doi.org/10.1007/BF00441954

[12] Stinus, L., Le Moal, M. and Koob, G.F. (1990) Nucleus accumbens and amygdale are possible substrate for the aversive stimulus effects of opiate withdrawal. Neuroscience, 37, 767-773.

http://dx.doi.org/10.1016/0306-4522(90)90106-E

[13] Pothos, E., Rada, P., Mark, G. and Hoebel, B.G. (1991) Dopamine microdialysis in the nucleus accumbens during acute and chronic morphine, naloxone precipitated withdrawal and clonidine treatment. Brain Research, 566, 348350. http://dx.doi.org/10.1016/0006-8993(91)91724-F

[14] Rada, P.V., Mark, G.P., Taylor, K.M. and Hoebel, B.G.
(1996) Morphine and naloxone ip or locally affect extracellular acetylcholine in accumbens and prefrontal cortex. Pharmacology Biochemistry and Behavior, 53, 809816. http://dx.doi.org/10.1016/0091-3057(95)02078-0

[15] Sepúlveda, M.J., Hernandez, L., Rada, P., Tucci, S. and Contreras, E. (1998) Effect of precipitated withdrawal on extracellular glutamate and aspartate in the nucleus accumbens of chronically morphine-treated rats: An in vivo microdialysis study. Pharmacology Biochemistry and Behavior, 60, 255-262. http://dx.doi.org/10.1016/S0091-3057(97)00550-9

[16] Kielstein, A., Tsikas, D., Galloway, G.P., Mendelson, J.E. (2007) Asymmetric dimethylarginine (ADMA) - A modulator of nociception in opiate tolerance and addiction? Nitric Oxide, 17, 55-59. http://dx.doi.org/10.1016/j.niox.2007.05.005

[17] Komatsu, T., Sakurada, C., Sasaki, M., Sanai, K., Tsuzuki, M., Bagetta, G., Sakurada, S., Sakurada, T. (2007) Extracellular signal-regulated kinase (ERK) and nitric oxide synthase mediate intrathecal morphine-induced nociceptive behavior. Neuropharmacology, 52, 1237-1243. http://dx.doi.org/10.1016/j.neuropharm.2007.01.003

[18] Harlan, R.E., Webber, D.S. and Garcia, M.M. (2001) Involvement of nitric oxide in morphine induced c-Fos expression in the rat striatum. Brain Research Bulletin, 54, 207-212. http://dx.doi.org/10.1016/S0361-9230(00)00451-2

[19] Garthwaite, J. (1991) Glutamate, nitric oxide and cell-cell signaling in the nervous system. Trends in Neuroscience, 14, 60-67. http://dx.doi.org/10.1016/0166-2236(91)90022-M

[20] Nestler, E., Alreja, M. and Aghajanian, M. (1994) Molecular and cellular mechanisms of opiate action: Studies in the rat locus coeruleus. Brain Research Bulletin, 35, 521-528. http://dx.doi.org/10.1016/0361-9230(94)90166-X

[21] Hope, B.T., Michael, G.J., Knigge, K.M. and Vincent, S.R. (1991) Neuronal NADPH diaphorase is a nitric oxide synthase. Proceedings of the National Academy of Sciences of the United States of America, 88, 2811-2814. http://dx.doi.org/10.1073/pnas.88.7.2811

[22] Vincent, S.R. and Kimura, H. (1992) Histochemical mapping of nitric oxide synthase in the rat brain. Neuroscience, 46, 755-784. http://dx.doi.org/10.1016/0306-4522(92)90184-4

[23] Sepúlveda, M.J., Ortega, A., Zapata, G. and Contreras, E. (2002) Acamprosate decreases the induction of tolerance and physical dependence in morphine-treated mice. European Journal of Pharmacology, 445, 87-91. http://dx.doi.org/10.1016/S0014-2999(02)01767-3

[24] Sepúlveda, J., Oliva, P. and Contreras, E. (2004) Neurochemical changes of the extracellular concentrations of glutamate and aspartate in the nucleus accumbens of rats after chronic administration of morphine. European Journal of Pharmacology, 483, 249-258. http://dx.doi.org/10.1016/j.ejphar.2003.10.037

[25] Paxinos, G. and Franklin, K.B.J. (2001) The mouse brain in stereotaxic coordinates. 2nd Edition, Elsevier, New York. 
[26] Bredt, D.S., Hwang, P.M., Glatt, C.E., Lowenstein, C., Reed, R.R. and Snyder, S.H. (1991) Cloned and expressed nitric oxide synthase structurally resembles cytochrome P450 reductase. Nature, 351, 714-718. http://dx.doi.org/10.1038/351714a0

[27] Garthwaite, J., Charles, S.L. and Chess-Williams, R. (1988) Endothelium-derived relaxing factor release on activation of NMDA receptors suggests role as intercellular messenger in the brain. Nature, 33, 385. http://dx.doi.org/10.1038/336385a0

[28] Bredt, D.S. and Snyder, S.H. (1992) Nitric oxide, a novel neuronal messenger. Neuron, 8, 3-11. http://dx.doi.org/10.1016/0896-6273(92)90104-L

[29] Leza, J.C., Lizasoain, I., San Martin-Clark, O. and Lorenzo, P. (1995) Morphine-induced changes on cerebral and cerebellar nitric oxide synthase activity. European Journal of Pharmacology, 285, 95-98. http://dx.doi.org/10.1016/0014-2999(95)00474-Y

[30] Cuellar, B., Fernandez, A.P., Lizasoain, I., Moro, M.A., Lorenzo, P., Bentura, M.L., Rodrigo, J. and Leza, J.C. (2000) Up-regulation of neuronal NO synthase immunoreactivity in opiate dependence and withdrawal. Psychopharmacology, 148, 66-73. http://dx.doi.org/10.1007/s002130050026

[31] Santamarta, M.T., Ulibarri, I. and Pineda, J. (2005) Inhibition of neuronal nitric oxide synthase attenuates the development of morphine tolerance in rats. Synapse, 57, 38-46. http://dx.doi.org/10.1002/syn.20151

[32] Mori, T., Ito, S., Matsubayashi, K. and Sawaguchi, T.
(2007) Comparison of nitric oxidesynthase inhibitors, phospholipase A2 inhibitor and free radical scavengers as attenuators of opioid withdrawal syndrome. Behavioural Pharmacology, 18, 725-729. http://dx.doi.org/10.1097/FBP.0b013e3282f18da6

[33] Smart, D. and Lambert, D.G. (1996) The stimulatory effects of opioids and their possible role in the development of tolerance. Trends in Pharmacological Sciences, 7, 264269. http://dx.doi.org/10.1016/0165-6147(96)10023-7

[34] Chen, L. and Huang, L.Y. (1991) Sustained potentiation of NMDA receptor-mediated glutamate responses through activation of protein kinase $\mathrm{C}$ by a mu opioid. Neuron, $\mathbf{7}$, 319-326. http://dx.doi.org/10.1016/0896-6273(91)90270-A

[35] Naassila, M., Hammoumi, S., Legrand, E., Durbin, P. and Daoust, M. (1998) Mechanism of action of acamprosate. Part I Characterization of spermidine-sensitive acamprosate binding site in rat brain. Alcoholism: Clinical and Experimental Research, 22, 802-809. http://dx.doi.org/10.1111/j.1530-0277.1998.tb03871.x

[36] Mayer, S., Harris, B., Gibson, D.A., Blanchard, J., Prendergast, M.A., Holley, R.C. and Littleton, J. (2002) Acamprosate has no effect on NMDA-induced toxicity but reduces toxicity induced by spermidine or by changing the medium in organotypic hippocampal slice cultures from rat. Alcoholism: Clinical and Experimental Research, 26, 655-662.

http://dx.doi.org/10.1111/j.1530-0277.2002.tb02587.x 